\title{
Improving Creative Thinking Through Creative Responsibility Based Learning (CRBL) Model
}

\section{G.A.T. Agustiana ${ }^{1 *}$, I Nyoman Tika ${ }^{2}$, dan Made Citra Wibawa ${ }^{3}$}

\author{
1,2,3 Universitas Pendidikan Ganesha, Singaraja, Indonesia
}

\section{ART I CLE INFO}

\section{Article history:}

Received August 09, 2021

Revised August 12, 2021

Accepted October 20, 2021

Available online November 25, 2021

\section{Kata Kunci:}

Model Creative Responsibility Based Learning (CRBL), Berpikir Kreatif, Efikasi Diri

\section{Keywords:}

Creative Responsibility Based Learning (CRBL) Model, Creative Thinking, Self-Efficacy

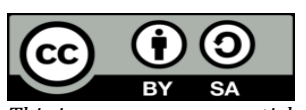

This is an open access article under the $C \mathrm{CC}$ BY-SA license.

Copyright (c) 2021 by Author. Published by Universitas Pendidikan Ganesha.

\begin{abstract}
A B S T R A K
Penggunaan berbagai model dan pendekatan masih menunjukkan bahwa siswa memiliki kendala dalam memahami konten IPA. Hambatan ini menyebabkan munculnya hambatan psikologis bagi siswa sehingga diperlukan keterampilan berpikir kreatif. Tujuan penelitian ini yaitu menganalisis perbedaan kemampuan berpikir kreatif antara siswa yang mengikuti model pembelajaran Creative Responsibility Based Learning (CRBL) dengan siswa yang mengikuti model pembelajaran konvensional ditinjau dari efikasi diri siswa dalam pembelajaran IPA. Jenis penelitian ini adalah penelitian eksperimen dengan desain Non-Randomized Post-test Only Control Group Design. Dalam desain ini pengambilan subjek tidak dilakukan secara acak. Jumlah anggota populasi adalah 184 siswa. Teknik yang digunakan untuk menganalisis data yaitu analisis deskriptif kualitatif, kuantitatif, dan statistika inferensial. Hasil penelitian yaitu hasil belajar IPA siswa yang mengikuti model pembelajaran CRBL lebih tinggi daripada siswa yang mengikuti model pembelajaran konvensional dengan nilai signifikansi 0,044<0,005. Terdapat perbedaan kemampuan berpikir kreatif antara siswa kelas IV SD yang memiliki efikasi diri tinggi dan efikasi diri rendah dalam pembelajaran IPA dengan nilai signifikansi 0,00<0,05). Terdapat pengaruh interaksi yang signifikan antara model pembelajaran dan efikasi diri terhadap keterampilan berpikir kreatif siswa dengan nilai signifikansi 0,00 < 0,05). Dapat disimpulkan model pembelajaran ini memberikan pengalaman belajar langsung kepada siswa dalam membangun selfefficacy dan kemampuan berpikir kreatif dalam mempelajari konsep-konsep dasar sains sehingga guru dapat menerapkannya.
\end{abstract}

\section{A B S T R A C T}

The use of various models and approaches still shows that students have difficulties understanding science content. This obstacle causes psychological barriers for students, so creative thinking skills are needed. The purpose of this study is to analyze the differences in creative thinking skills between students who follow the Creative Responsibility Based Learning (CRBL) learning model and students who follow the conventional learning model in terms of students' selfefficacy in learning science. This type of research is an experimental study with a Non-Randomized Post-test Only Control Group Design. In this design, the subject is not taken randomly. The number of population members is 184 students. The techniques used to analyze the data are qualitative descriptive analysis, quantitative, and inferential statistics. The result of the research is that the science learning outcomes of students who follow the CRBL learning model are higher than students who follow the conventional learning model with a significance value of $0.044<0.005$. There is a difference in creative thinking ability between fourth grade elementary school students who have high selfefficacy and low self-efficacy in science learning with a significance value of $0.00<0.05$ ). There is a significant interaction effect between the learning model and self-efficacy on students' creative thinking skills with a significance value of 0.00 $<0.05)$. It can be concluded that this learning model provides direct learning experiences to students in building selfefficacy and creative thinking skills in learning basic science concepts so that teachers can apply them.

\section{INTRODUCTION}

Natural science is one of the subjects obtained by elementary school students. Natural science is the meaning of nature and its various phenomena, packaged into theories and concepts through a scientific process (Wardani \& Syofyan, 2018; Widiartini et al., 2018, 2019). Science goes through a systematic process and is considered a means of developing attitudes and values in students (Cemara \& Sudana, 2019; Dewi et al., 2016; Jannah et al., 2020).Science learning can improve students' scientific, critical thinking skills, and religious attitudes (Jupriyanto, 2018; Syafi'ah, 2019). Learning is a process of teaching and learning activities involving teachers and students to achieve predetermined goals/indicators (Latipah et al., 2020; Puspitarini \& Hanif, 2019; Wichadee, 2011). Science learning must lead students to master science concepts 
and their relationships to solve problems in everyday life by science attitudes. Students are expected to know and memorize science concepts and understand these concepts and connect the relationship between one concept and other concepts (Arisantiani et al., 2017; Dwi Lestari \& Putu Parmiti, 2020; Seika Ayuni et al., 2017). However, in reality, many students still do not understand science learning well. Previous research also stated that some students still have difficulty learning science (Pramana \& Suarjana, 2019; Santiasih et al., 2013). It has an impact on students' low thinking skills. Various intervention efforts by education experts in facilitating science learning have been carried out to build creative thinking skills in elementary school students, namely interventions including using inquiry teaching models, storytelling, crossword puzzles, instruction-based learning, approaches (Akhmalia et al., 2018; Dewi et al., 2017; Syarifah \& Sumardi, 2015). The use of various models and approaches still shows that students have difficulties understanding science content. It is based on the fact that science is a complex subject with many abstract and often counter-intuitive concepts (Atmojo, 2012; Fuadi et al., 2020; Gasila et al., 2019).

This obstacle causes the emergence of psychological barriers for students to uncover natural phenomena in the abstract realm, so creative thinking skills are needed (Lestari et al., 2019; Wulandari et al., 2019). By Piaget's theory of cognitive development, creative thinking skills can be better adapted to early grades, namely in children's knowledge development (Moma, 2017; Suparmi, 2019). Interventions to trigger good creative thinking skills can be started from learning science in elementary schools (Dilla et al., 2018; Marliani, 2015). Science learning outcomes for elementary school students are relatively low, caused by several factors, namely, the use of teacher teaching methods that are not appropriate, so that students only memorize and do not understand the material. Second, the ability of teachers to motivate children is still low, so it is necessary to start a new approach to learning for elementary school students. Third, there are misconceptions because they cannot think abstractly. Creative thinking ability is positively correlated with science learning outcomes.

The ability to think creatively also decreases. This condition shows that the higher the self-efficacy, the higher the ability to think creatively (Magelo et al., 2019; Ulandari et al., 2019). Self-efficacy can harm student behaviour. One of them is that students can avoid multitasking, a very challenging task while working on it (Turan \& Koç, 2018; Utami \& Wutsqa, 2017; Zysberg \& Schwabsky, 2020). Students who have self-efficacy perceive it as a challenge and want to solve it. Confidence in his ability is one of the noncognitive factors that affect science learning outcomes. One of the learning models that teachers can use to overcome these problems is the Creative Responsibility Based Learning (CRBL) learning model. This learning model makes students no longer learn most of the knowledge, but students are facilitated to apply their scientific knowledge to solve life problems. Students can be involved in meaningful learning and have greater responsibility for completing scientific investigations and scientific creativity tasks. The CRBL design is supported by constructivism theory, reciprocal relationship model, metacognition, complex cognitive processes, advanced organizer, and scaffolding. The findings of previous studies also state that an appropriate learning model can help students learn (Azmi, 2015; Seika Ayuni et al., 2017; Selamet, 2017). Other research findings also state that learning models adapted to students can improve science learning outcomes in students (Cintia et al., 2018; Dewi et al., 2016; Seika Ayuni et al., 2017). It can be concluded that a suitable learning model can help students learn. The purpose of this study is to analyze the differences in creative thinking skills between students who follow the Creative Responsibility Based Learning (CRBL) learning model and students who follow the conventional learning model in terms of students' self-efficacy in learning science.

\section{METHOD}

This type of research is experimental research. The experimental design used in this study was the Non-Randomized Post-test Only Control Group Design. In this design, subject taking was not done randomly. This design was chosen because the experiment was carried out in certain classes with existing or as-is students, and during the experiment, it was not possible to change the existing class. The research analysis design was a $2 \times 2$ factorial design. The sorting factor is the moderator self-efficacy variable. The separator is divided into two levels: self-efficacy above the group average $(27 \%$ from above. Below the group average ( $27 \%$ from the bottom), the data is sorted from the largest to the smallest. This sorting is expected to increase the accuracy of the research. The level separation is pseudo-level, meaning that during the experimental activities, the students are not significantly separated between students who have selfefficacy above and below the group average. The population in this study were all fourth-grade students at SD Gugus I, Buleleng District, Buleleng Regency, totaling 8 elementary schools. The total number of population members is 184 students, the following is the composition of grade IV students in Cluster I, Buleleng District, Buleleng Regency. Data collection in this study included: (1) student achievement motivation, and (2) student learning outcomes in chemistry subjects. In summary, the data collection 
methods used in this study can be seen in Table 1 . The techniques used to analyze the data are qualitative descriptive analysis, quantitative, and inferential statistics.

Table 1. Techniques of Collection Data and Instruments

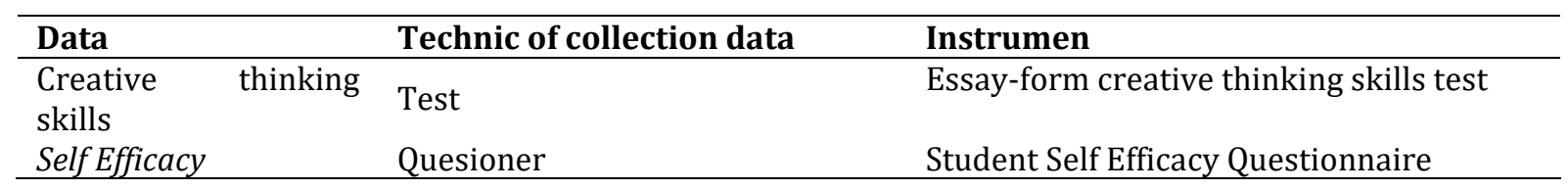

\section{RESULT AND DISCUSSION}

\section{Result}

Self-efficacy as a moderator variable shows that classes taught by subject teachers have never measured students' self-efficacy towards science learning in elementary schools. In the interviews and observations, students still tend to be apathetic towards science. It is also expected to decrease or decrease student self-efficacy. Because the ability to think creatively also decreases, this condition shows that the higher the self-efficacy, the higher the ability to think creatively. Self-efficacy may harm student behaviour. One is that students can avoid multitasking lessons, incredibly challenging tasks while doing. Those who have self-efficacy perceive it as a challenge and want to solve it. Confidence in their abilities is one of the non-cognitive factors that affect science learning outcomes. Such conditions do not depend on luxury, other people and uncontrollable external factors. Seeing the vital role of self-efficacy in the learning process with the Creative Responsibility Based Learning (CRBL) model provides a meaningful experience so that spurring self-efficacy in a positive direction is one of the goals that researchers want to achieve.

The research data shows that the variance homogeneity test was conducted using Levene's Test of Equality of Error Variances through SPSS 14. Calculating the significance of $0.059>0.005$ means that the data is homogeneous. The science learning outcomes of students who take the CRBL learning model are higher than students who take the conventional learning model $(\mathrm{Fh}=11.288>\mathrm{Ft}(\alpha=0.05 .1: 88)=3.96)$ with a significant value of $0.044<0.005$, (2) there is a difference in creative thinking skills between grade IV elementary school students who have high self-efficacy and low self-efficacy in science learning (Fh = $29,836>$ Ft $(\alpha=0.05,1: 88)=3.96$ with significance value $0.00<0.05)$, and (3) there is a significant interaction effect between learning models and self-efficacy on students' creative thinking skills (Fh = $16,783>$ Ft $(\alpha=0.05,1: 88)=3,96$ with a significance value of $0.00<0.05)$. The creative thinking skills used during the implementation of learning shown in the phases of the Creative Responsibility Based Learning (CRBL) model are highly relevant to the dual coding theory, which have implications for positive responses from students. Students respond that learning involving the use of the Creative Responsibility Based Learning (CRBL) model is interesting and provides new experiences.

\section{Discussion}

The learning model syntax describes the entire activity steps, which are generally followed by a series of learning activities that are structured logically and systematically (Balan et al., 2019; Dewi et al., 2016; Fitria \& Idriyeni, 2017). The syntax for the CRBL model begins with Phase 1: Generating creative responsibility. The teacher tries to raise the students' self-confidence so that they want to be responsible for being creative. The teacher's role as a facilitator can increase students' enthusiasm for learning (Albu, 2013; Dewi et al., 2016; Nurtanto et al., 2021). Teachers can motivate students by asking about using objects for scientific purposes, conveying learning objectives and the importance of responsibility for creativity (Liu et al., 2020; Schildkamp et al., 2020). Students are accustomed to conveying objects for scientific purposes as much as possible, understanding learning objectives, and the importance of responsibility for overcoming barriers to creativity in themselves. It can train students' scientific thinking skills (Misla \& Mawardi, 2020; Saraswati \& Agustika, 2020; Wulandari et al., 2019).

Phase 2: Organizing creative learning needs. Teachers create a free, open, democratic, and positive investigative learning environment critical to developing scientific creativity. Students are creative when the learning environment stimulates and encourages independent thinking (Arianti, 2017; Farid, 2014; Lonanda et al., 2015). Phase 3: Guiding group investigations. Teachers facilitate the development of scientific process skills, responsibility, and creativity in group investigations to build their scientific knowledge. The teacher's role is to present problems that have not been clearly defined to produce several strategies and solutions (Adiningtiyas, 2017; Buchari, 2018).

Assign responsibility for demonstrating scientific creativity. The teacher facilitates the development of scientific creativity and student responsibility in exploring the various impacts of the 
development of science and technology. Students can express their creative ideas by making scientific creativity test questions and alternative solutions, then communicating the results in front of the class. It is in line with the theory of complex cognitive processes that mastery of divergent thinking can produce innovative products (Hermes et al., 2019; Low et al., 2019; Paul \& Singh, 2020). Students can also re-discuss material concepts in textbooks that are poorly understood. Stage 5: Evaluation and reflection. The teacher involves students in evaluating the mastery of science process skills and scientific creativity, reflecting on responsibilities during the learning process, and follow-up for subsequent meetings. The involvement of students in planning, implementing, and evaluating the learning process makes a significant contribution to the achievement of their responsibilities (Aristiani, 2016; Maharani \& Kristin, 2017; Rahayu et al., 2019). This condition is in line with the learning model's various challenges to face real challenges. This condition is by the skills demanded by 21st-century learning (Bedir, 2019; Gelen Assoc, 2018; Rahayu et al., 2019). Prepare children to face an increasingly complex and rapidly changing world.

\section{CONCLUSION}

There are differences in creative thinking skills between students who follow the Creative Responsibility Based Learning (CRBL) learning model and students who follow the conventional learning model. There are differences in creative thinking abilities in students who have high self-efficacy who follow the Creative Responsibility Based Learning (CRBL) learning model and students who follow the conventional learning model. There are differences in creative thinking abilities in students who have low self-efficacy who follow the Creative Responsibility Based Learning (CRBL) learning model and students who follow the conventional learning model. There is an interaction between the learning model and selfefficacy on students' creative thinking skills in science subjects. This learning model provides a direct learning experience for students in building self-efficacy and creative thinking skills in learning basic science concepts so that teachers can apply them.

\section{REFERENCES}

Adiningtiyas, S. W. (2017). Peran Guru dalam Mengatasi Kecanduan Game Online (Teacher's Role in Overcoming Online Game Addiction). KOPASTA: Jurnal Program Studi Bimbingan Konseling, 4(1), 28-40. https://doi.org/10.33373/kop.v4i1.1121.

Akhmalia, N. L., Suana, W., \& Maharta, N. (2018). Efektivitas Blended Learning Berbasis LMS dengan Model Pembelajaran Inkuiri pada Materi Fluida Statis terhadap Penguasaan Konsep Siswa. JIPFRI (Jurnal Inovasi Pendidikan Fisika Dan Riset Ilmiah), 2(2), 56-64. https://doi.org/10.30599/jipfri.v2i2.299.

Albu, G. (2013). The Teacher-headmaster and his Relationship with Himself. Procedia - Social and Behavioral Sciences, 78. https://doi.org/10.1016/j.sbspro.2013.04.369.

Arianti. (2017). Urgensi lingkungan belajar yang kondusif dalam mendorong siswa belajar aktif. Didaktika Jurnal Kependidikan, 11(1), 41-62. https://doi.org/10.30863/didaktika.v11i1.161.

Arisantiani, N. K., Putra, M., \& Ganing, N. N. (2017). Pengaruh Model Pembelajaran Childrens Learning In Science (Clis) Berbantuan Media Lingkungan Terhadap Kompetensi Pengetahuan IPA. Journal of Education Technology, 1(1). https://doi.org/10.23887/jet.v1i2.11774.

Aristiani, R. (2016). Meningkatkan Percaya Diri Siswa Melalui Layanan Informasi Berbantuan Audiovisual. Jurnal Konseling Gusjigang, 2(2), 182-189. https://doi.org/10.24176/jkg.v2i2.717.

Atmojo, S. E. (2012). Profil Keterampilan Proses Sains Dan Apresiasi Siswa Terhadap Profesi Pengrajin Tempe Dalam Pembelajaran IPA Berpendekatan Etnosains. Jurnal Pendidikan IPA Indonesia, 1(2). https://doi.org/10.15294/jpii.v1i2.2128.

Azmi, N. (2015). Model Pembelajaran Inside Outside Circle (Ioc)) Untuk Meningkatkan Hasil Belajar Siswa Dalam Proses Pembelajaran. Al Ibtida: Jurnal Pendidikan Guru MI, 2(1), 1-19. https://doi.org/10.24235/al.ibtida.snj.v2i1.180.

Balan, L., Yuen, T., \& Mehrtash, M. (2019). Problem-Based Learning Strategy for CAD Software Using FreeChoice and Open-Ended Group Projects. Procedia Manufacturing, 32, 339-347. https://doi.org/10.1016/j.promfg.2019.02.223.

Bedir, H. (2019). Pre-service ELT teachers' beliefs and perceptions on 21st century learning and innovation skills (4Cs). Journal of Language and Linguistic Studies, 15(1), 231-246. https://doi.org/10.17263/jlls.547718.

Buchari, A. (2018). Peran Guru Dalam Pengelolaan Pembelajaran. Jurnal Ilmiah Iqra', 12(2), 106. https://doi.org/10.30984/jii.v12i2.897.

Cemara, G. A. G., \& Sudana, D. N. (2019). Pengaruh Model Pembelajaran SAVI Bermuatan Peta Pikiran Terhadap Kreativitas dan Penguasaan Kompetensi Pengetahuan IPA Siswa. Jurnal Ilmiah Sekolah 
Dasar, 3(3), 359-368. https://doi.org/10.23887/jisd.v3i3.18895.

Cintia, N. I., Kristin, F., \& Anugraheni, I. (2018). Penerapan Model Pembelajaran Discovery Learning Untuk Meningkatkan Kemampuan Berpikir Kreatif Dan Hasil Belajar Siswa. Perspektif Ilmu Pendidikan. https://doi.org/10.21009/pip.321.8.

Dewi, E. P., Suyatna, A., Abdurrahman, A., \& Ertikanto, C. (2017). Efektivitas Modul dengan Model Inkuiri untuk Menumbuhkan Keterampilan Proses Sains Siswa pada Materi Kalor. Tadris: Jurnal Keguruan Dan Ilmu Tarbiyah, 2(2), 105. https://doi.org/10.24042/tadris.v2i2.1901.

Dewi, Kusmariyatni, \& Margunayasa. (2016). Pengaruh Model Pembelajaran Learning Cycle 5E Terhadap Hasil Belajar IPA Siswa Kelas V SD. Mimbar PGSD Undiksha, 4(1). https://doi.org/10.23887/jjpgsd.v4i1.6658.

Dilla, S. C., Hidayat, W., \& Rohaeti, E. E. (2018). Faktor Gender dan Resiliensi dalam Pencapaian Kemampuan Berpikir Kreatif Matematis Siswa SMA. Journal of Medives : Journal of Mathematics Education IKIP Veteran Semarang, 2(1), 129. https://doi.org/10.31331/medives.v2i1.553.

Dwi Lestari, H., \& Putu Parmiti, D. P. P. (2020). Pengembangan E-Modul IPA Bermuatan Tes Online Untuk Meningkatkan Hasil Belajar. Journal of Education Technology, 4(1), 73. https://doi.org/10.23887/jet.v4i1.24095.

Farid, M. M. (2014). Pengaruh Motivasi Belajar, Gaya Belajar, Dan Lingkungan Belajar Pada Hasil Belajar Ekonomi Di SMA Negeri 1 Wringinanom Gresik. Jurnal Ekonomi Pendidikan Dan Kewirausahaan, 2(2), 142-156. https://doi.org/10.26740/jepk.v2n2.p142-156.

Fitria, Y., \& Idriyeni, I. (2017). Development of Problem-Based Teaching Materials for The Fifth Graders of Primary School. Jurnal Ta'dib, 20(2), 99-106. https://doi.org/10.31958/jt.v20i2.747.

Fuadi, H., Robbia, A. Z., Jamaluddin, J., \& Jufri, A. W. (2020). Analisis Faktor Penyebab Rendahnya Kemampuan Literasi Sains Peserta Didik. Jurnal Ilmiah Profesi Pendidikan, 5(2). https: //doi.org/10.29303/jipp.v5i2.122.

Gasila, Y., Fadillah, S., \& Wahyudi. (2019). Analisis Keterampilan Proses Sains Siswa Dalam Menyelesaikan Soal IPA Di SMP Negeri Kota Pontianak. Jurnal Inovasi Dan Pembelajaran Fisika (JIPF). https://doi.org/10.36706/jipf.v6i1.10399.

Gelen Assoc, I. (2018). Academicians' Predictions Of 21 St Century Education And Education In The 21 St Century. European Journal of Education Studies, 4, 165-204. https://doi.org/10.5281/zenodo.1233478.

Hermes, M., Albers, F., Böhnke, J. R., \& Huelmann, G. (2019). Measurement and structural invariance of cognitive ability tests after computer-based training. Computers in Human Behavior, 93. https://doi.org/10.1016/j.chb.2018.11.040.

Jannah, I. N., Prasetiyawati, D., Hariyanti, D., \& Prasetyo, S. A. (2020). Efektivitas Penggunaan Multimedia dalam Pembelajaran IPA di SD. 4(1), 54-59.

Jupriyanto, J. (2018). Kemampuan Berpikir Kritis Siswa Dalam Pembelajaran Ilmu Pengetahuan Alam Kelas IV. Jurnal Ilmiah Pendidikan Dasar, 5(2), 105. https://doi.org/10.30659/pendas.5.2.105-111.

Latipah, E., Kistoro, H. C. A., \& Khairunnisa, I. (2020). Scientific Attitudes in Islamic Education Learning: Relationship and the Role of Self-Efficacy and Social Support. Edukasia: Jurnal Penelitian Pendidikan Islam. https://doi.org/10.21043/edukasia.v15i1.7364.

Lestari, S. P., Muhandaz, R., \& Risnawati, R. (2019). Pengaruh Penerapan Pendekatan Open-Ended terhadap Kemampuan Berpikir Kreatif Matematis Berdasarkan Kemandirian Belajar Siswa Sekolah Menengah Pertama Negeri 2 Pekanbaru. JURING (Journal for Research in Mathematics Learning) UIN Sultan Syarif Kasim Riau, 2(3), 239-248. https://doi.org/10.24014/juring.v2i2.7504.

Liu, Y., Bellibaş, M. Ş., \& Gümüş, S. (2020). The effect of instructional leadership and distributed leadership on teacher self-efficacy and job satisfaction: Mediating roles of supportive school culture and teacher collaboration. Educational Management Administration and Leadership, 1-24. https://doi.org/10.1177/1741143220910438.

Lonanda, S., Yolamalinda, \& Stevi. (2015). Pengaruh Kesiapan Belajar, Lingkungan Belajar Dan Peranan Orangtua Terhadap Hasil Belajar Ekonomi Siswa Kelas Ips Di SMA PGRI 4 Padang. Journal of $\begin{array}{llll}\text { Economic and } \quad \text { Economic } & \text { Education, }\end{array}$ https: //doi.org/10.1017/CB09781107415324.004.

Low, E. L., Ng, P. T., Hui, C., \& Cai, L. (2019). How do teacher affective and cognitive self-concepts predict their willingness to teach challenging students? Australian Journal of Teacher Education, 44(10), 18-34. https://doi.org/10.14221/ajte.2019v44n10.2.

Magelo, C., Hulukati, E., \& Djakaria, I. (2019). Pengaruh Model Pembelajaran Open-Ended terhadap Kemampuan Berpikir Kreatif Matematik Ditinjau dari Motivasi Belajar. Jambura Journal of Mathematics, 2(1), 15-21. https://doi.org/10.34312/jjom.v2i1.2593.

Maharani, O. D. tri, \& Kristin, F. (2017). Peningkatan Keaktifan dan Hasil Belajar IPS Melalui Model 
Pembelajaran Kooperatif Tipe Make A Match. WACANA AKADEMIKA: Majalah Ilmiah Kependidikan, 1(1), 1-12. https://doi.org/10.30738/wa.v1i1.998.

Marliani. (2015). Peningkatan Kemampuan Berpikir Kreatif Matematis Siswa melalui Model Pembelajaran Missouri Mathematics Project (MMP). Jurnal Ilmiah Pendidikan MIPA, 5(1), 14-25. https://doi.org/10.30998/formatif.v5i1.166.

Misla, M., \& Mawardi, M. (2020). Efektifitas PBL dan Problem Solving Siswa SD Ditinjau dari Kemampuan Berpikir Kritis. Jurnal Ilmiah Sekolah Dasar, 4(1), 60. https://doi.org/10.23887/jisd.v4i1.24279.

Moma. (2017). Pengembangan Kemampuan Berpikir Kreatif dan Pemecahan Masalah Matematis Mahasiswa Melalui Metode Diskusi. Cakrawala Pendidikan, 36(1), 130-139.

Nurtanto, M., Kholifah, N., Masek, A., Sudira, P., \& Samsudin, A. (2021). Crucial problems in arranged the lesson plan of vocational teacher. International Journal of Evaluation and Research in Education (IJERE), 10(1), 345-354. https://doi.org/10.11591/ijere.v10i1.20604.

Paul, R., \& Singh, A. (2020). Does early childhood adversities affect physical, cognitive and language development in indian children? Evidence from a panel study. SSM - Population Health, 12(August), 100693. https://doi.org/10.1016/j.ssmph.2020.100693.

Pramana, I. P. Y., \& Suarjana, I. M. (2019). Pengaruh Model Pembelajaran Time Token Berbantuan Media Video Terhadap Hasil Belajar IPA Kelas V SD. Journal of Education Technology, 2(4), 137. https://doi.org/10.23887/jet.v2i4.16425.

Puspitarini, Y. D., \& Hanif, M. (2019). Using Learning Media to Increase Learning Motivation in Elementary School. Anatolian Journal of Education, 4(2), 53-60. https: //doi.org/10.29333/aje.2019.426a.

Rahayu, I. P., Christian Relmasira, S., \& Asri Hardini, A. T. (2019). Penerapan Model Discovery Learning untuk Meningkatkan Keaktifan dan Hasil Belajar Tematik. Journal of Education Action Research, 3(3), 193. https://doi.org/10.23887/jear.v3i3.17369.

Santiasih, N. I., Marhaeni, A. A. I. N., \& Tika, I. N. (2013). Pengaruh Model Pembelajaran Inkuiri Terbimbing Terhadap Sikap Ilmiah dan Hasil Belajar IPA Siswa Kelas V SD No. 1 Kerobokan Kecamatan Kuta Utara Kabupaten Badung Tahun Pelajaran 2013/2014. Jurnal Pendidikan Dasar Ganesha, 3(1). https://doi.org/10.23887/jet.v3i1.17959 Article Metrics.

Saraswati, P. M. S., \& Agustika, G. N. S. (2020). Kemampuan Berpikir Tingkat Tinggi Dalam Menyelesaikan Soal HOTS Mata Pelajaran Matematika. Jurnal Ilmiah Sekolah Dasar Undiksha, 4(2). https: //doi.org/10.23887/jisd.v4i2.25336.

Schildkamp, K., Kleij, van der, Heitink, Kippers, W. B., \& Veldkamp, B. P. (2020). Formative assessment: A systematic review of critical teacher prerequisites for classroom practice. International Journal of Educational Research. https://doi.org/10.1016/j.ijer.2020.101602.

Seika Ayuni, I. G. a. P. A., Kusmariyatni, N., \& Japa, I. G. N. (2017). Pengaruh Model Pembelajaran Talking Stick Berbantuan Media Question Box Terhadap Hasil Belajar Ipa Kelas V. Journal of Education Technology, 1(3), 183. https://doi.org/10.23887/jet.v1i3.12503.

Selamet, N. W. (2017). Pengaruh Model Pembelajaran Numbered Head Together Berbasis Tri Kaya Parisudha Terhadap Hasil Belajar IPS Siswa Kelas IV". E- Journal PGSD Universitas Pendidikan Ganesha. MIMBAR PGSD Undiksha, 5(2), 1-11. https://doi.org/10.23887/jjpgsd.v5i2.10768.

Suparmi, N. W. (2019). Hasil Belajar Pemahaman Konsep Dan Berpikir Kreatif Siswa Dalam Pembelajaran Inkuiri Bebas Dan Inkuiri Terbimbing. Journal of Education Technology, 2(4), 192. https: //doi.org/10.23887/jet.v2i4.16548.

Syafi'ah, R. (2019). Analisis Muatan Nilai-Nilai Karakter Pada Buku Pegangan Siswa Ipa Smp Kelas VII Semester 2 Kurikulum 2013. LENSA (Lentera Sains): Jurnal Pendidikan IPA, 9(1), 30-36. https://doi.org/10.24929/lensa.v1i1.61.

Syarifah, \& Sumardi, Y. (2015). Pengembangan Model Pembelajaran Malcolm'S Modeling Untuk Meningkatkan Keterampilan Berpikir Kritis Dan Motivasi Belajar Siswa. Jurnal Inovasi Pendidikan IPA, 1(2), 237. https://doi.org/10.21831/jipi.v1i2.7510.

Turan, M. B., \& Koç, K. (2018). The impact of self-directed learning readiness on critical thinking and selfefficacy among the students of the school of physical education and sports. International Journal of Higher Education, 7(6), 98-105. https://doi.org/10.5430/ijhe.v7n6p98.

Ulandari, N., Putri, R., Ningsih, F., \& Putra, A. (2019). Efektivitas Model Pembelajaran Inquiry terhadap Kemampuan Berpikir Kreatif Siswa pada Materi Teorema Pythagoras. Jurnal Cendekia: Jurnal Pendidikan Matematika, 3(2), 227-237. https://doi.org/10.31004/cendekia.v3i2.99.

Utami, R. W., \& Wutsqa, D. U. (2017). Analisis kemampuan pemecahan masalah matematika dan self-efficacy siswa SMP negeri di Kabupaten Ciamis. Jurnal Riset Pendidikan Matematika, 4(2), 166. https: //doi.org/10.21831/jrpm.v4i2.14897.

Wardani, R. K., \& Syofyan, H. (2018). Pengembangan Video Interaktif pada Pembelajaran IPA Tematik Integratif Materi Peredaran Darah Manusia. Jurnal Ilmiah Sekolah Dasar, 2(4), 371. 
https://doi.org/10.23887/jisd.v2i4.16154.

Wichadee, S. (2011). Developing The Self-Directed Learning Instructional Model To Enhance English Reading Ability And Self-Directed Learning Of Undergraduate Students. Journal of College Teaching \& Learning (TLC), 8(12), 43. https: //doi.org/10.19030/tlc.v8i12.6620.

Widiartini, P. D. O., Made Putra, M. P., \& Manuaba, I. B. S. (2019). Pengaruh Model Pembelajaran Group Investigation Berbasis Tri Hita Karana Terhadap Kompetensi Pengetahuan IPA. Jurnal Ilmiah Sekolah Dasar. https: //doi.org/10.23887/jisd.v3i3.19476.

Widiartini, P. D. O., Putra, M., \& Manuaba, S. (2018). Pengaruh Model Pembelajaran Group Investigation Berbasis Tri Hita Karana Terhadap Kompetensi Pengetahuan IPA. Jurnal Ilmiah Sekolah Dasar, 3. https://doi.org/10.23887/jisd.v3i3.19476.

Wulandari, F. A., Mawardi, M., \& Wardani, K. W. (2019). Peningkatan Keterampilan Berpikir Kreatif Siswa Kelas 5 Menggunakan Model Mind Mapping. Jurnal Ilmiah Sekolah Dasar, 3(1). https://doi.org/10.23887/jisd.v3i1.17174.

Zysberg, L., \& Schwabsky, N. (2020). School climate, academic self-efficacy and student achievement. Educational Psychology, O(0), 1-16. https://doi.org/10.1080/01443410.2020.1813690. 